Article

\title{
Towards a Typology of Battlefield Miracles: The Case of Operation "Cast Lead" in the Israel Defense Forces
}

\section{Elisheva Rosman}

Department of Political Studies, Bar Ilan University, Ramat Gan 5290002, Israel; rosmane@biu.ac.il

\begin{abstract}
Battlefield miracle stories are not rare. This paper suggests a typology of battlefield miracles. From this perspective it asks what sort of miracles can we expect to see in battle and when can we expect to see them? After presenting the main points of discussion regarding miracles, it proposes a range of categories for military miracles (miracles as acts that violate nature versus miracles as everyday acts; those involving the divine versus occurrences not requiring the presence of a heavenly emissary; acts of benevolence versus acts with no such intent; having a clear purpose versus acts where there is disagreement regarding interpretation). After discussing these categories, the articles uses Operation Cast Lead (December 2008-January 2009) as a case study to test the typology suggested above. Since this field is underdeveloped, this paper sets out to initiate a conversation on battlefield miracles, with hope that future studies will build upon it.
\end{abstract}

Keywords: miracles; battlefield; Rachel the Matriarch; Israel Defense Forces; typology

\section{Introduction}

Battlefield miracle stories ${ }^{1}$ are not rare. While they usually do not manifest themselves as blatantly as the appearance of a venerated figure appearing in battle, they are nevertheless a presence on the battlefield: rain beginning or ceasing as needed by the troops; a holy book stopping bullets, signs interpreted by troops as favorable, victory against terrible odds, as well as many other examples. They are, in a sense, the appearance of religion in everyday life (Ammerman 2014).

Religion is viewed ambiguously in liberal democracies. On the one hand, personal belief is seen as a right that should be upheld. On the other hand, in many contexts, it is seen as a threat to the state. According to this view, church and state should not mix, and allowing religion into public discourse can be a dangerous "foot in the door". In this context, permitting religious arguments in the public sphere, accepting religion as a legitimate presence within armed forces or schools, is a threat to the secular, liberal nature of the modern state (for many examples, see: Bardon 2016). Similarly, miracles and the appearance of miracles in the public sphere are viewed as hoaxes and manipulations at best. In more extreme cases, officially recognizing an event as a miracle can serve anti-democratic forces and generates antagonism. In the age of science, the belief in miracles, particularly in the public sphere, is perceived as primitive and frowned upon. It is, therefore, not surprising that battlefield miracles are not the focus of much scholarship.

However, religion is not disappearing from the public sphere and, in some cases, is only growing stronger. Likewise, in some situations, religion can be a positive force, such as serving as a motivational power on the battlefield or as a psychological coping mechanism (Heilman and Witztum 2000). It is imperative to understand the effect religion still has on citizens and soldiers if scholars are to gauge the relationship between church and state in the 21st century: when does it come into play even regarding secular citizens, what its strengths and weaknesses are, and how these

As opposed to actual miracles. This paper makes no attempt to discuss the validity of miracles, but rather focuses on miraculous stories. Therefore, when making reference to miracles, it is important to note that the paper is referring to the way the miracle is related, as a miraculous story. 
manifest themselves in the public sphere. This effect is interdisciplinary. It is relevant not only to religious studies, political science and political thought, but also to fields such as military sociology, civil-military relations, and psychology. In this sense, the exploration of battlefield miracles can contribute to the understanding of the effects religion has in the modern world.

This paper does not attempt to ask "are miracles true?" or "what really happened?"2 Its point of departure is that people believe in miracles on the battlefield and do not think they are imagining them, hallucinating or lying. Their premise is that they indeed witnessed something miraculous, and whether or not others believe these events to have occurred is irrelevant. As Weddle (2010, p. 8) rightly asserts, miracles happen only when they are a possibility. They must have a proper context and audience in order to appear. Therefore, this paper seeks to present tools to categorize battlefield miracles. From this perspective, it asks when can we expect reports of battlefield miracles and what sort of miracles can we expect to see in certain battles?

Since this field is very underdeveloped, this paper sets out to initiate a conversation on battlefield miracles, with hope that future studies will develop and elaborate upon this topic. The study constructs a typology of battlefield miracles, tests the typology on a case study and attempts to discern what types of battlefield miracles are likely to surface in what type of setting.

The present paper begins with a survey of the literature regarding miracles in general and battlefield miracles in particular. After proposing a typology of battlefield miracles, the article turns to a case study (Operation Cast Lead, 2008-2009) in order to test it. The case study is presented using a survey of local Israeli media analyzed through content analysis. The case study indicates that miracles appear in context: soldiers who experience miracles tend to witness those that are in line with their own religion. Additionally, it seems that battlefield miracles are more likely to present themselves when soldiers are influenced by a religious mindset. In its final section, the paper suggests possible understandings of the case study miracles and proposes ideas for future work.

\section{Miracles and Battlefield Miracles: A Survey of the Literature}

Miracles are difficult to define. They are usually seen as something extraordinary, surprising, or unexpected. Miracles are also subjective. Considering a given event a miracle may be disputed, even between theists (Basinger 2011). To rephrase the well-known expression, people know a miracle when they see one, even if it escapes definition. This becomes clearer when we consider that miracles are supposed to inspire a sense of awe. Different people consider different things to be awe-inspiring and these differences of opinion can influence the definitions of miracles. Therefore, while the following pages cannot possibly offer a definitive characterization of miracles, they will attempt to sketch a broad range of categories for miracles. ${ }^{3}$

Miracles can be seen as violations of natural laws (Hume [1777] 1900, p. 120), an intentional intervention of a supernatural force in the natural course of things. This is not always a clear concept. Does the intervention have to be intentional? Must it be something that cannot be replicated or explained? What happens if, in the future, a scientific explanation for the occurrence is found, rendering it un-miraculous? (Basinger 2011, pp. 27-28). This understanding of miracles ties in with Christian traditions. For example, in the process of canonization of would-be saints, it must be proven that the miracle was created by the intentional intercession by the candidate for canonization, and that there is no other possible explanation for the occurrence. Similar conditions for miracles can be found in Islam.

Opposing this position, is Augustine's opinion (Augustine 1876, XXI, 5; 8) that miracles do not have to be contrary to nature. They are contrary to human understanding of nature and, therefore, surprise us, causing us to wonder (miriari-to wonder; miriaculum-miracle) and be awestruck, but

2 Such thinking is not very helpful when trying to understand the phenomenon of miracles in general, as shown by Yoram Bilu. See for example: (Shani 2015).

3 The following discussion will focus predominantly on the three main monotheistic religions, Islam, Christianity and Judaism, with special attention given to Judaism due to the case study presented. Miracles in other religions take on other forms. While these are also very worthy of exploration, the scope of the present paper does not allow me to include them in depth. 
they are not a violation of nature or its laws. This idea can be expanded to include perfectly natural occurrences as miracles: the divine caused something normal to occur in order for something extraordinary to happen (Basinger 2011, pp. 24-25). According to this understanding, the event's miraculous aspect lies in its timing and not in the event itself. That an event can be explained through nature does not make it un-miraculous, so to speak. ${ }^{4}$ What is miraculous is that something happened at an exact time and place that brought about a feeling that a miracle took place. In this sense, another way of understanding a miracle is that it is an event that causes people to be acutely aware of divine presence (Basinger 2011, p. 31). Consequently, in some traditions, miracles are seen as commonplace and mundane-the ability to breathe or a natural healthy birth, for example. Everything in life is wondrous and, therefore, it is all a miracle. ${ }^{5}$ In traditional religions, miracles may be accepted as part of the natural order.

In this sense, it seems that the philosophical debate on the nature of miracles might be discussing two meta-categories of miracles, and not entirely disagreeing with each other. Rather, each school of thought can be seen as an opposite end of a spectrum of miracles, ranging from overtly blatant interventions in nature (resurrection, walking on water, the parting of a sea) to more "mundane" events that seem to be natural or can be explained naturally (rain falling when needed, an enemy overlooking the hiding place of the faithful, the appearance of an item that seemed lost, victory in battle despite unfavorable odds). These types can be seen as "ideal types" of miracles, with a range of other categories existing on a continuum in between them.

As stated, the philosophical debate on miracles tends to begin with Hume and his definition given above, ${ }^{6}$ and focuses on two main aspects of the topic: what is a miracle? Is it reasonable to believe miracles occur? (Diamond 1973; Landrum 1976; Taylor 2007). From there the discussion continues to arguments in favor or against the belief in miracles as well as the precise definition of a miracle, whether it is indeed a violation of the course of natural events and whether it is connected to an act on part of a deity. In any case, such miracles are usually perceived as positive (Bowie 2011, p. 169). Larmer (2011) classifies a miracle as having three characteristics: it would not have happened were it not for a rational supernatural power; it has religious significance "in the sense that it can reasonably be viewed as furthering God's purposes"; it is such an extraordinary event that the only plausible explanation is that it was a supernatural intervention in the natural order of things.

However, the philosophical discussion of miracles is not the only one. Scholars of religion tend to look at miracles in another light. Weddle (2010) for example, sees miracles as an opportunity for hope. They do not create faith, but rather inspire wonder, causing us to think (Weddle 2010, pp. 2325). They present the possibility that even when all is lost, something might still be saved. His definition for miracles does not include the divine at all: "a miracle is an event of transcendent power that arouses wonder and carries a religious significance for those who witness it or hear or read about it" (Weddle 2010, p. 4). In other words, the importance and meaning of the miracle lies with the beholder and may be unconnected to a deity.

This definition highlights one of the main problems when discussing miracles. A miracle is based on belief. Belief, as opposed to fact, is like an opinion. It depends on certain assumptions (Lamont 2013). If it is raining outside, it is not a matter of opinion or belief. It is either raining or it is not. Whether an occurrence is a miracle or not, is a matter of opinion or belief. It is completely subjective.

Accordingly, it seems that arriving at an agreed-upon definition for miracles is impossible. Not only can theorists not agree on the extraordinary-versus-natural point, but they disagree on the role God(s) plays in miracles. Basinger (2011, p. 32) claims that, for theists, a miracle must involve the

4 See thoughts in a similar vein in: (Moberly and Walter 2011, pp. 57-74). For an opposing view: (Weddle 2010, pp. 14-18).

5 See, for example, a Jewish approach to miracles putting forth this idea: (Issacs 1997; Birnbaum 1984). For an opposing view: (Weddle 2010, pp. 14-18). This idea echoes research ideas brought before by Ammerman (2014) on how as scholars, it is important to search for religion in everyday life-anything can be a religious experience, it depends on how and where we look.

6 For background on Hume's text and the context within which the debate regarding miracles evolved, see: (Burns 1981; Weddle 2010). 
divine. Larmer (2011, p. 47) and Weddle (2010, p. 4) disagree with this assumption. Most theists see miracles as positive: God intervening on behalf of the faithful for their benefit (Basinger 2011, p. 32). On the other hand, other scholars point out that miracles are not always beneficial and meant "to do good". They can serve as a punishment or may be a way to prove the invoker of the miracle has certain powers related to the divine (Loebenstein 2003; Weddle 2010).

It is, therefore, not surprising that typologies of miracles are not prevalent and those that exist, focus on narrow categories (for example: Zelyck 2016; Schulz 2013; Fiordalis 2012). This may be in part because specific typologies (levitation miracles, knowledge-related miracles, food-related miracles, healing miracles, and so on) are better at addressing a specific tradition. While this sort of typology can be useful, it is also limiting (Weddle 2010), mainly because it does not look at miracles in a broader context, but instead remains at the most basic level of taxonomy.

To the best of my knowledge, the only attempt to classify miracles into a typology along broader lines was done by Loebenstein (2003) concerning miracles in medieval Islam, specifically, regarding differences between the Sunni and Shi'i opinions on miracles. ${ }^{7}$ Loebenstein demonstrates that miracles can fit into a number of categories:

- An action beyond human capabilities that is created by humans, not angels (harq al-ada).

- An action meant as proof of something (such as: the person performing the miracle is indeed a prophet, as he claims to be) (mu'giza). This type of miracle is public, and is also an action beyond human capabilities, created by a human.

- An action carried out in secret, does not aim to be proof of anything, but is also an act beyond human capabilities (karama).

This typology is in line with Islamic traditional thought concerning miracles. In both Islam and Judaism, the word for Quranic or Biblical miracles is better translated as a "sign" or "proof" (aya, bayyina, dalil in Islam and ot, mofet in Judaism). ${ }^{8}$ Examined in such a manner, miracles can be included in more neutral categories and do not have to be bound to a deity, to the concept of benevolence or be out of the ordinary; they can be all or any of the above, depending on their purpose. It is their purpose which defines them best. This brings us back to the idea that miracles must be discussed in the context of those who witness them and frame them as miracles. If we define miracles according to their aim or purpose, what matters is how they are interpreted and what they are perceived as teaching or indicating.

Building upon Loebenstein's typology, and with the previous literature in mind, and accepting that miracles depend on context, we can perceive the following categories of miracles:

- miracles as acts that violate natural order, versus miracles as everyday acts

- miracles as involving the divine in some form, versus miracles as not requiring the presence of a God or heavenly emissary of any sort, and can even be carried out by humans under certain conditions

- miracles as acts of benevolence, versus miracles with no intent of "doing good"

- miracles with a clear purpose or aim, versus miracles where there is disagreement regarding their interpretation

Each of these categories can be visualized as a continuum, with ideal types of miracles at each end and the ability to consider individual cases as "more" or "less" (for example, being seen as a positive act of benevolence, being somewhat benevolent but also serving as punishment, and so on). Keeping these categories in mind, the following section examines battlefield miracles in particular.

\section{Battlefield Miracles}

7 Gilman (1989) in his discussion of miracles does draw two broad categories of miracles (explainable in natural terms and inexplicable in natural terms). However his focus is not in creating a typology and, therefore, seems less relevant in the present context.

8 See: (Loebenstein 2003; Issacs 1997). 
Religion as a general concept plays an important part on the battlefield. It gives soldiers a sense of purpose, helps in sense-making within the chaos of the battlefield, and in general allows soldiers to view their role in battle in a positive way. It can also boost soldiers' morale, cause them to perform acts of bravery and, at times, might tip the battle in their favor. The scope of this paper prevents a closer examination of the many aspects of the impact religion has both on performance in battle and coping after it. Religion can serve as a source of empowerment for soldiers and as a coping mechanism. For some, it enables sensemaking on the battlefield. This topic has been explored extensively (for some examples see: S. Cohen 1997; Cohen 2016; Hassner 2014, 2016; Hegghammer 2010; Pargament 2011; Pargament et al. 1990, 1992; Witvliet et al. 2004), and this paper by no means attempts to cover it in depth. In the context of the present study, one important aspect of religion in battle, relevant to the present discussion, is the observance of military miracles.

Battlefield miracles fit in with the ideas brought forth here. First, they can be seen as miracles that serve a national purpose (proving "our gods are stronger than yours"). ${ }^{9}$ They can also be placed on the spectrum ranging from an occurrence that is perceived as an overt violation of nature, to an occurrence that seems natural, but its timing or the way it occurred leads believers to think it has supernatural causes. From ancient times to the present, soldiers have seen angels fight by their side (the visions of Joan of Arc, George Washington's vision of an angel at Valley Forge, to name but two), seen signs promising victory (Constantine seeing a heavenly sign before the Battle of Milvian Bridge, Joshua encountering God's commander of war before the battle of Jericho), called upon God to assist them in winning and created a miracle (Joshua stopping the sun from setting in the Valley of Ayalon, Muhammad throwing sand at his adversaries during the Battle of Badr and blinding them); and felt that they won despite great odds (the Maccabees against the Greeks; the victory against the Ottomans during the siege of Vienna).

Likewise, military miracles can be invoked by the divine or by humans: angels, heroes, generals who felt they were guided by the supernatural, ranging from Joshua and Gideon to Muhammad, King Henry V, and George Washington. Such miracles can be seen as acts of benevolence or as punishment: God saving the Israelites and punishing the Egyptians on the Red Sea; Confederate troops seeing their defeat as punishment and a sign from heaven to mend their ways; ${ }^{10}$ the victory of the Six Day war perceived by Israelis as a sign of God's favor and deliverance. Usually military miracles' purposes-when discerned-are to prove which side the divine is on and/or to call upon soldiers (and nations) to become more religious and god-fearing.

Very little has been written on miracles on the battlefield, most of it in passing (Hassner 2014; 2016; S. Cohen 2016). However, soldiers have always told of miracles during war. From biblical times to the 21st century, God (or an emissary on his behalf) has taken part in battle, rescuing, deflecting the enemy and bestowing victory, or at least preventing defeat. Biblical military miracles are famous and in many cases involve direct intervention of God on the battlefield. Modernity and the secularization of western society have not abolished battlefield miracles, though these have become less overt.

Perhaps the most famous miracles in battle in modern times involve saints or the appearance of heavenly figures during battle. During World War I, for example, soldiers testified to viewing: St. Therese of Lisieux (Hassner 2016); Joan of Arc and St. Michael (Clarke 2002); the "White Helper", understood to be Jesus (Clarke 2002); and heavenly horsemen (not to be confused with the Angels of Mons, who may or may not have appeared $)^{11}$ who accompanied troops falling back during the battle of Le Cateau (McClure 1994).

These are extraordinary miracles. When reported, they are frequently given widespread publicity, as the examples from World War I given above, or examples from the Mujahidin in Afghanistan (Al-Azzam n.d.) illustrate. Personal battlefield miracles are more commonly related,

9 For ancient examples: (Garland 2011).

10 For example, Shattuck describes how during the Civil War, Confederate defeat was perceived by Southern Evangelicals as God's punishment; see: (Shattuck 1987, pp. 40-43).

11 For a full discussion of the story of the Angels of Mons and whether or not the miracle was witnessed on the battlefield or based on a fictional story written by a journalist; see: (Machen 1915; McClure 1994). 
with individual soldiers recounting their stories of survival and framing them as miraculous. These are not as published or well-known (for some more modern examples: Goodwin 2015; Freeman and Wright 2001). Personal miracles can include the appearance of a holy figure who delivers the soldier. For example: St. Michael saving a marine during the Korean War (TFP Student Action n.d.); or a Sikh Guru saving a British officer during World War II (the officer subsequently converted to Sikhism, (Sikhi Wiki 2012)); a Taliban fighter saved by four mysterious men and later a mysterious woman who gave him water and returned his magazine pouch (Miracles in the Jihad in Afghanistan 2015).12 However, personal miracles can also take the form of signs soldiers interpret as miracles, such as rain ceasing or beginning as needed, clouds forming to protect troops, and so on (for example: Hassner 2016; Winer 2014).

Miracles can be publicized during the events (as happened during the World Wars) or after the fact (such as the case of Operation Cast Lead in Israel). Very often, general miracles have no clear origin and are difficult to verify or trace, such as the attempts by Clarke (2002) and McClure (1994) to unravel the story of the Angels of Mons. Personal miracles are easier to trace, due to the fact an individual is willing to testify (in writing, film, or otherwise) that the event occurred (for example: Miracles in the Jihad in Afghanistan 2015). However, even in these cases, many times the miracle is attributed to "someone I know", rather than a person with a specific identity (as in the cases mentioned above: TFP Student Action n.d.; Sikhi Wiki 2012).

To the best of my knowledge, no typology of battlefield miracles has been conducted, certainly not one that attempts to unravel the meaning soldiers attach to them. Battlefield miracles can fit into the categories sketched above:

- miracles as acts that violate natural order versus miracles as everyday acts;

- miracles as involving the divine in some form versus miracles as not requiring the presence of a God or heavenly emissary of any sort and can even be carried out by humans under certain conditions;

- miracles as acts of benevolence versus miracles with no intent of "doing good"; or

- miracles with a clear purpose or aim versus miracles where there is disagreement regarding their interpretation

A given battlefield miracle can fit in different places on each of these continuums (for example, a miracle not created by a divine emissary, but violating nature, saving troops and proving their cause is just).

The aspect of battle is particularly important within the final category. Miracles on the battlefield usually have a clear purpose regarding the battle (God is on our side; our God is stronger than the adversary's God; God is rewarding us for our piety or for repenting and becoming more firm in our belief in him; God is punishing us for our pride and wrongful ways so that we may repent and regain his favor). In general, victory in battle is viewed-since ancient times and until the 21st century-as a sign of God's favor. The righteous, those who recognize God's power and the "true religion", are rewarded. Failure is viewed as a punishment and an opportunity to repent. Additionally, victory can be seen as God calling on soldiers to recognize his power and become more religiously observant. They were not saved because they were worthy, but because God wished to demonstrate his abilities to the enemy. In all cases, the feeling that God is present on the battlefield is interpreted by soldiers (provided they are religiously inclined) as a calling to be more religious and recognize God.

Another important point to note is that military miracles have a religious context. They build upon accepted concepts of miracles. ${ }^{13}$ For example, the Mujahidin in Afghanistan reported multiple cases of miracles that go against nature, but not created by a deity: the bodies of Mujahidin did not decay after death (Al-Azzam n.d., pp. 32-33), body parts and blood of dead Mujahidin gave off a

12 These experiences may correspond to the phenomenon referred to as "Third Man Factor," where individuals report feeling a presence directing them to behave in a way that enables them to save themselves from a lifethreatening situation: see (Geiger and Dale 2009). However, in the cases reported here, an actual figure is reported, rather than a feeling of a presence.

13 For similar insights see: (Stolz 2011, pp. 15-16). 
wonderful fragrance (Miracles in the Jihad in Afghanistan 2015). These miracles are not duplicated in other religions and lean on Islamic tradition regarding miracles and afterlife of martyrs in general. Since the case study used below involves a predominantly-Jewish military (the Israel Defense Forces, IDF), it is imperative to view the Jewish context of miracles.

Miracles in Judaism have undergone a transformation over time. While in biblical times, miracles tended to violate nature (the parting of the Red Sea for example, Elisha resurrecting the dead), miracles in post-exile Judaism are not extraordinary events, but rather miraculous in their timing. Even in the time of the Talmud, rabbis were uncomfortable with the concept of miracles intervening in nature (Pearl 1988; Mackler 2007). Jewish theologists and scholars note that miracles, certainly after the Talmudic period, tend to be everyday occurrences interpreted as miracles, rather than events that violate nature. This does not mean that there are no miracles in post-Talmudic Judaism that defy nature, only that this is not the prevalent type of miracles. ${ }^{14}$ The general accepted mode for miracles, surely in modern times, is in the interpretation given to them (Heschel 1955, chp. 4; Baumgarten 1983; Birnbaum 1984). Additionally, miracles are not a precondition to faith in Judaism (Birnbaum 1984), and therefore are not universally accepted. While seeing God's presence in everyday acts is acceptable, miracles that are blatant interventions in nature are frowned upon, certainly by the mainstream.

When might we expect to see miracles on the battlefield? It seems that soldiers, being in intense, life-threatening situations, in need of making order out of the chaos of battle, are good candidates for reporting miraculous stories. In trying to explain reality to themselves and to find hope in an extreme situation, miracles are a coping mechanism. Further to this, based on previous, similar, incidents (such as the World Wars), it seems that when soldiers feel God is on their side of the conflict, there is higher probability for hearing reports of miracles. Additionally, if soldiers are in need of justifying their actions, to themselves or to others, they may be more inclined to feel God is "on their side" and frame their experiences as miracles.

Another possible hypothesis in this context, is that when soldiers are in the proper state of mindmany are religious individuals in their civilian lives, there is a noticeable religious presence on the battlefield, the war itself has been framed in religious terms, and so on - they will be more open to observing miracles.

Using the categories depicted above, we may now turn to the case of a modern military operation and test these ideas further.

\section{Methodology and Presentation of the Case Study}

Miracles gain meaning when publicized. As Weddle (2010, pp. xi-xiii) posits, the important point to consider when examining miracles is to ask what they mean for those who experience them and hear about them. In the 21st century, few battlefield miracles have gained widespread coverage. This may be due to the fact that in the internet age, it is harder to have unexplained phenomenon. When everything can be photographed or videoed, analyzed, and then presented as photoshopped, there is little room for miracles to occur. However, that does not mean there are no modern battlefield miracles.

The current study focuses on a military operation where miracles of various types receive coverage. The research plan used to test the categories suggested, was to follow mainstream media, looking for reports of miracles during the conflict and for some time after its conclusion. This allowed

14 It seems that even the original stories of the Baal Shem Tov (the Besht) did not include miracles that were blatant interference in nature, although such stories were added over the years to the miracles attributed to him by his disciples (Dan 1990, pp. 90-91). Indeed, there were those in Hasidism who opposed the use of such miracles, though stories, particularly attributed to the Besht, exist. Many (though not all) of the miracles of subsequent Hasidic masters were not ones the interfered with the laws of nature, but are usually a result of timing: the Rebbe's prayers enable something to happen. However, other than time-manipulation miracles, most of these miracles do not involve a change in nature. Birnbaum (1984) illustrates how Hasidic miracles that do violate nature are considered "inferior" miracles and are not prevalent. I thank Zvi Mark for his insights on this issue. 
real-time monitoring of public opinion regarding miracles and publicity (if any) of the miracles at the time of their sightings. At the same time, more marginal media was also followed: Internet forums, message boards, minor and more sectarian or religious news sites, social media (such as WhatsApp messages), and so on. These sources are more likely to cover reports of miracles and discuss them than mainstream media. In the information age, these sources are varied and hold vast amounts of information.

Using media as a way of gauging public opinion has been employed extensively in media studies (Rosman and Israeli 2015). The ever-growing presence of the media in the public sphere, together with the fact that the media is the public's main source of information, have served as an impetus for scholars to examine the role played by the media in society (Cohen-Almagor 1994; Cohen-Almagor and Yanovitzky 1999). The media organizes and classifies social knowledge and the world of social images for its audience (framing) and, thus, determines what does and does not appear on the public agenda. This organization and classification is selective and in accordance with society's prevailing norms and values (Almond 1960). Put differently, the media reinforces the status quo. It takes part in formulating society's beliefs, in framing its hopes, in consolidating its vocabulary and its collective memory, but it is society which allocates the channels through which the media can operate and sets down rules. In other words, the media is part of the system of social, cultural and political modes of expression and works within it (Roeh 1994). Therefore, it is a good indication of public opinion, norms, and values. Thus, examining the way battlefield miracles are portrayed in the media or are absent from its discourse reflects public feelings on the topic.

This research design also has limitations. Media is not only influenced by the public, but shapes public opinion. The media is incapable of reflecting reality perfectly, since every event can be seen from more than one perspective and has more than one interpretation. During this process, society's central values become set and their significance sealed by the media. Change in those values are both reflected in and promoted by media coverage. For the purpose on the present study, this limitation is not necessarily detrimental. Following the media, in this case, demonstrates the "proper" way miracles are perceived in society: what is mainstream and what is marginal. If the media accepts miracles and publicizes them, this tells a different story than the one to be heard if the media ignores miracles and leaves them to only marginal venues.

At the same time, systematically following reports of miracles in the information age is complicated. When these sightings occur during protracted conflicts, the length of conflict makes it difficult to systematically collect all of the miraculous occurrences and analyze them. Therefore, in order to test the viability of the categories suggested above, it seems better to focus on a concentrated military operation. Operation Cast Lead (2008-2009) lasted three weeks and two days and included a broad range of miraculous incidents on the Israeli side, some of which were documented in writing and film/audio. Its length, as well as the fact that at the time social media was less developed than today, allow a more systematic examination of sources in order to follow miracles. In this sense, it serves as an important case study. It is concentrated enough in order to allow for an in-depth examination of the categories proposed, its media coverage was extensive but not unmanageable, and it featured a number of incidents portrayed as miracles. If indeed this typology proves helpful, it will require future studies to test it on longer conflicts, including both sides of a given conflict, but the current case study can begin the conversation since it will be able to indicate if the proposed typology is constructive.

One of the most publicized modern battlefield miracles took place during this operation: the miraculous appearance of Rachel the Matriarch in Gaza. ${ }^{15}$ Her appearance was corroborated by a number of individuals who were willing to repeat their testimonies on film or radio; one identifying himself by name as well (Ovadiya 2009; Arutz 7 News 2009). These individuals testified they saw Rachel themselves and spoke to her. While their stories are not identical, they are very similar. Additional miracles of various types were also reported regarding the operation. The short length of the operation, together with the fact that Israel does not boast many daily national papers, and its volume of internet publications at the time was manageable, enabled a systematic review of the

15 For a discussion of the significance of Rachel in Jewish folk belief in Israel see: (Sered 1991, 1995). 
publication of miraculous occurrences. Thus, the operation is a good case study for gauging battlefield miracles, certainly in the 21st century. ${ }^{16}$

Operation Cast Lead (Oferet Yetzuka) ${ }^{17}$ began on 27 December 2008. The operation began with airstrikes, and on 3 January 2009 ground forces entered Gaza. The operation ended on 18 January 2009 with a ceasefire between Israel and Hamas. ${ }^{18}$

Following Weddle (2010) and his ideas regarding the meaning of miracles, in order to gauge public feelings toward battlefield miracles, three prominent Israeli daily print newspapers were examined: Yediot Aharonot and Yisrael Hayom, as representative of tabloids, and Haaretz as a broadsheet. ${ }^{19}$ Since these papers present a broad spectrum of public opinions in the Israeli public, it was expected that they would mirror views on miracles during the operation. ${ }^{20}$ In addition, Internet publications of these papers throughout the operation were also followed. Relevant Internet publications during this period were also collected (specifically message boards, which were prevalent at the time, such as Behadrei Haredim and FXP; news sites such as Mako and Arutz 7 [also known also as INN]) and searches using all possible key words in order to find later publications were also run. Publications were monitored for the duration of the operation as well as the week after the ceasefire was reached. Additionally, all publications were searched for further mention of miracles for the remainder of 2009 and the following years (2010-2016). Articles and opinion pieces were analyzed for the framing of incidents as miracles and the position taken by the paper. Headlines were of particular importance in this context as they are considered to voice the opinion of the editors. Aside from written sources, video sources were also searched, particularly YouTube and Vimeo where individuals can upload personal videos. Addtionally, radio stations were searched in order to find other sources describing miraculous incidents. All of these sources were analyzed using content analysis techniques (based on Seidman 2013; Thomas 2006; Miles et al. 1994; Patton 1990) to assess if incidents were viewed as a miracle and how they were framed.

\section{Findings}

Following content analysis of all of these sources, a number of insights can be reached. First, during the fighting itself, no overt miracles were reported. One incident was labeled "a miracle" by Yisrael Hayom and Yediot Ahraonot, but was not a battlefield miracle: a rocket falling on a classroom, causing only damage (Yisrael Hayom, 1 January 2009, p. 5; Yediot Aharonot, 1 January 2009, p. 5). Yediot published several photos of soldiers praying or in religious settings during the operation (for example: 4 January 2009, p. 1). However, these were very few and far between and included no mention of miracles. Haaretz made no reference to miracles in any way for the entire duration of the

16 Other possible case studies include the war in Afghanistan from the point of view of the Mujahidin (for example: (Al-Azzam n.d.; Miracles in the Jihad in Afghanistan 2015), US Marines in Iraq (Thomas 2005), as well as others. Here, too, testimonies of miracles were documented in writing and sometimes on film. However, all of these wars were protracted conflicts and attempting to comprehensively follow all sightings and reports of miracles is very difficult to do systematically. I hope future studies explore the understanding of these miracles as well.

17 This is not to imply that the operation was considered a miracle, but that miraculous events were reported during this operation.

18 Since the miracles discussed here are from the Israeli side of the conflict, other aspects are not discussed.

19 Media studies in Israel usually focus on these three daily papers as indicators of general media trends. For a comprehensive explanation of these papers and how indicative they are of Israeli public opinions and trends, see: (Rosman and Israeli 2015; Limor et al. 2014; Caspi and Limor 1992, 1999). All three newspapers were searched for articles, photos, and opinion pieces dealing with miracles and using religious terms. The papers were collected from 25 December 2008 (two days before the operation began) and until 25 January 2009 (one week after the end of the operation). News pages as well as supplements were all included. Additionally, a search for all relevant key words was run (when possible) to reveal additional pieces that might have been published on this topic during the years following the operation. Additional Internet searches focusing on electronic communications during the operation and in its aftermath were also run.

20 Since my focus was Israeli opinions, English-language publications were not covered systematically, as were Hebrew-language publications. 
operation. It even went so far as to show the opposite. For example, in a story reporting that rabbis promised that graves of famous rabbis buried in the town of Netivot would protect the town, it was stressed that a rocket fell near the grave of the venerated kabbalist, the Baba Sali ${ }^{21}$ (Yagna 2009). In other words, hardly any miracles were reported during the actual fighting, and these were civilianrelated occurrences reported in the more popular press. The elite publication made efforts to send an opposing message and no military miracles were reported at all.

One military-related occurrence was publicized during the actual fighting and later would be framed by some as a miracle, though at the time it was most certainly not portrayed as one. A unit sleeping in a school, accidently discovered that it was wired with explosives (Yisrael Hayom, 12 January 2009, p. 3). The story was covered in more detail with many photos by Yediot, but, again, not framed as a miracle (Yediot Aharonot, 12 January 2009, pp. 2-3).

Reports of miracles began to surface in the mainstream media only after the operation was completed, and these were mostly a response to publications in more marginal venues (message boards and sectarian news sites). The most famous of these was the report regarding the appearance of Rachel the Matriarch. Stories regarding her appearance began to circulate in message boards at the end of the operation. Mainstream media mentioned the incident in opinion pieces only (Zini 2009a, 2009b; Daum 2009; D. Cohen 2009); with none of the papers devoting any time to the story in any way.

Contrary to similar cases of battlefield miracles in the past (Clarke 2002), actual soldiers went on record claiming to have met Rachel in battle. Four testimonies regarding her appearance were recorded: three in a movie made after the operation named "How G-d Fought in Gaza" (Ovadiya 2009) and one in a radio broadcast. During the radio broadcast, an interview on the religious Arutz 7 channel, the interviewee (a soldier who brought supplies to troops) described how he was with a group of soldiers who wanted to enter a building. A woman's voice warned them not to enter. They then saw a figure made of light, hovering, with no hands or feet. They tried to enter the building, but she warned them: "there is death in the house" and not to enter. All of the soldiers saw her, but she spoke only to one soldier, the interviewee Avner Azulai. "I asked who she is. She said, in these words: "I am Mother Rachel". I began to shake" (Arutz 7 News 2009). The group returned later with sappers who found the house to be wired with explosives. Azulai claimed that when he consulted rabbis later to ask them about the incident, he was told that Rachel spoke only to him because he is a descendant of the HIDA (R. Haim Yosef David Azulai 1724-1806), a famous rabbi and Kabbalist (Arutz 7 News 2009).22

The other three testimonies were given on film by three unnamed soldiers, an officer and two conscripts, each interviewed separately. They recounted how an old Arab woman (an actual figure, as opposed to Azulai's testimony) told the soldiers to leave a building that then blew up. They wanted to enter a second building when the woman appeared again and told them not to enter, that the building was wired, and it indeed blew up. The third time she appeared and warned them not to enter, they asked her who she was and she answered that she is Rachel the Matriarch (Ovadiya 2009). All three soldiers were filmed in settings that look like post-battle rest periods, indicating the filmmaker visited them during the actual events and filmed them while they were still under the influence of their battlefield experiences. ${ }^{23}$

These testimonies were publicized during May 2009. However, rumors concerning this miracle began to circulate toward the end of the operation, in mid-January. A number of prominent rabbis published responses to the miracle stories. R. Mordechai Eliyahu, a former Chief Rabbi of Israel, a

21 For an understanding of the meaning the Baba Sali holds in Israel, see: (Bilu and Ben-Ari 1995).

22 For an in-depth study on the significance of Rachel the Matriarch see: (Sered 1995; Sered 1991).

23 Similar stories were published in English language publications, but these had additional information that did not exist in other publications. For example, in a story in the English edition of Nahshoni 2009b), Rachel was described "a beautiful young women" while in all of the other (oral and written) testimonies in Hebrew she was certainly not described this way. Another description appeared in a blog and told the story in a completely different way, although citing Hebrew sources that did not include this information (Bee 2009). It seems that all the stories published in English were based on the same source. 
respected religious authority and a known kabbalist, claimed he sent the matriarch to save troops (Nahshoni 2009a, Daum 2009). According to his son's testimony, R. Eliyahu went to pray at Rachel's tomb a number of times before the operation and asked her to "intercede on behalf of her children during the upcoming conflict" (Nahshoni 2009a). ${ }^{24}$ This was the sole endorsement of the incident as a miracle from a religious authority.

Conversely, R. Yosef Zini, a rabbi in the city of Ashdod and father of a brigade commander during the operation, published three opinion pieces (Zini 2009a, 2009b, 2009c) saying the story was a complete fabrication. ${ }^{25}$ R. Shlomo Aviner, an extremely influential rabbi in the Religious Zionist sector, also opposed the story and said there might perhaps be a more rational explanation for this event (for example, that the woman was a Jewish woman who married a Palestinian and moved to Gaza or that she was a righteous gentile who wanted to prevent more bloodshed) (Nahshoni 2009a). Likewise, R. Yuval Cherlow, another prominent Religious Zionist rabbi, vehemently opposed the story and called it a "manipulation" (Daum 2009). As a rule, with the noted exception of the aforementioned R. Eliyahu, rabbis who involved themselves in the issue questioned the occurrences were miracles and even spoke out against them.

While the story of Rachel the Matriarch was the most well-known during the months after the operation, other miracles were also discussed. Of these, there were a number of military miracles. These were reported by minor publications and internet forums. Interestingly, the testimony of an officer from the Givati brigade regarding miracles, was filmed and later published online in the film cited above (Ovadiya 2009). The officer, whose face is obscured but rank is visible, was filmed speaking to troops at the end of the operation. He is discussing the operation, and as part of this lecture, tells of "three miracles" (his words) he witnessed during the operation. The first, is the story of the soldiers who slept in a school and discovered by chance that it was rigged with explosives. It was framed by the officer as a miracle; the same incident described in newspapers above, but framed differently. The second incident is a story regarding a fire that broke out in a building some of the troops were in, but injured no one; also framed by the officer as a miracle. The third, a story recounting the accidental finding of a well-stocked offensive enemy tunnel ready to serve as a venue for kidnapping soldiers, also framed as a miracle. At the end of his talk, the officer noted that "the entire operation [...] I felt the prayers of the entire Jewish People following us, with us" (Ovadiya 2009). In his opinion, the prayers are what brought about the miracles. This testimony is important in that it is a good gauge of feelings within the military itself. The film was obviously taken in an official setting. The officer is speaking to his soldiers after the operation. It is not clear he is even aware of the fact he is being filmed. It seems that when telling of these events, his main purpose is to boost morale and give his soldiers a feeling of victory and accomplishment.

Other testimonies in the movie recount near-misses such as an RPG rocket fired and missing an entire unit, a soldier who waiting an extra minute before leaving a room, thereby avoiding a direct hit, wounds that looked serious but turned out to be superficial, and so on. Each of the interviewees framed their story as a miracle and noted that after the incident, soldiers became more religious, wearing ritual fringes, praying, reciting psalms, laying phylacteries, and so on (Ovadiya 2009).

The film also interviewed various soldiers recounting how all troops, even non-Jewish ones, wanted to wear ritual fringes in battle, requested psalm books to carry with them, and more (Ovadiya 2009). This was viewed as one of the reasons miracles occurred during the fighting. ${ }^{26}$ Almost all of the interviews seem to have been filmed in military venues of various types (either in the field or on military bases) and most of the interviewees are in uniform.

Additional miracles reported in internet forums, message boards and so on, included: heavy rain falling before the ground troops entered Gaza so that the ground was muddy and absorbed

24 See also the testimony itself in Hebrew: <https://www.youtube.com/watch?v=3XeH0npoWJA $>, 20$ January 2009 (downloaded: February 2016).

25 The pieces are almost identical, but obviously the rabbi made an effort to have them published in as many venues as possible: two daily newspapers and a popular Internet forum.

26 It is important to note that the film was ridiculed in mainstream media. See: (Gazit 2009; Blau 2009a, 2009b). 
many of the rockets in such a way that some did not explode and that the shrapnel of those that did explode was absorbed by the mud (for example: Yahadoot 2012).

All of these incidents received most of their coverage from marginal publications; mostly ultraorthodox (haredi) or Zionist ultra-orthodox (haredi-leumi). After circulating in message boards and minor news sites, they were discussed in mainstream media minimally, but only as part of opinion pieces, mostly dismissing the framing of these occurrences as miracles. Clearly, they were not seen as news-worthy and were mostly painted as rumors, if not blatant manipulations and lies. There was public discomfort over the publication of the miracles in mainstream media, both popular and elite publications, ${ }^{27}$ but more acceptance of the phenomena in sectarian (mostly ultra-orthodox) and marginal media. Evidently, the venues where miracles were publicized were peripheral and had no support from mainstream media or even from mainstream sectarian media. Public figures, including religious public figures, went to great lengths to discredit the idea of miracles during the operation and, in general, it seems that all mainstream media refused to see them as miraculous in any way. This is true for both religious and secular mainstream publications. Events framed as miracles received legitimacy "from below" - the troops themselves and, to a lesser degree, from marginal publications.

\section{Battlefield Miracles in Context}

When placed within the suggested typology presented above, the miracles in Cast Lead fit into clear categories on the spectrum depicted earlier:

- $\quad$ All of the miracles were perceived as everyday acts. None were overt interventions in natural order. Rachel's acts did not violate nature. Even in Azulai's testimony, while she is clearly a heavenly emissary, her actions are not extraordinary.

- One miracle involved a heavenly emissary (Rachel). All of the others did not require divine presence of any sort. This fits in with the fact that all of the miracles were perceived as everyday acts with no need for overt intervention on the part of the divine.

- All of the miracles were seen as positive acts of benevolence (saving of soldiers).

- $\quad$ All of the miracles were understood as having a clear purpose and reason: they were an answer to prayers, a way for the divine to indicate which side it was on, and a sign to become more religious.

Interestingly, while it seems that soldiers accepted the incidents as miracles and interpreted them as such, in the civilian sphere, they were not viewed necessarily as positive events. Not only did secular Israelis oppose the idea of miracles on the battlefield during the operation, but rabbis and religious Israelis also opposed viewing the incidents as miracles, as demonstrated above..$^{28}$

Another observation worth noting is that following operations had no parallel miracles. Quite the opposite. Instead of reports of miracles, jokes circled in social media referring to the appearance of Rachel in Cast Lead and ridiculing it. For example, during Operation Protective Edge (July 2014), two jokes circulated in WhatsApp forums specifically playing off the sighting of Rachel five years earlier. The first joke, recounted the same story from 2009, ends with the soldiers going to sleep in the second house and discovering in the morning that the woman was actually Leah (referring to the biblical story of Jacob, Rachel, and Leah). The second joke begins with soldiers planning to enter a building and being warned by two boys. When asked who they were, the younger boy answered: I am Efraim and this is my brother Menashe [Biblical Joseph's sons], Grandma [Rachel] was busy and

27 Interestingly, parallel reactions can be found in Islamic contexts. The responses to reports of miracles in Afghanistan included ridicule as well: see (Stout 2010).

28 In this context, it is important to note that while a large percentage of IDF soldiers are religious or traditional (mesorati, in this context-meaning they maintain strong ties to folk religion), there is much tension between general Israeli society and the way it perceives the roles religion plays within the ranks. This topic is quite volatile in Israel and has been explored extensively in the literature. See: (S. A. Cohen 1997, 2008, 2016; Rosman-Stollman 2014; Levy 2015; Cohen and Susser 2014); as well as many others. 
couldn't come. ${ }^{29}$ Furthermore, the same filmmaker who documented the miracles in Cast Lead, Yuval Ovadiya, made a movie supposedly recounting miracles from Operation Protective Edge. However, this movie barely reports miracles that occurred during the operation and features no military miracles at all. Instead it focuses on calling the faithful to become more observant in their belief (Ovadiya 2014). Since the filmmaker had already stated in the past (Gazit 2009) that his objective was to inspire religious feelings, had he obtained any evidence of additional miracles, he certainly would have presented it in the second film as well.

The type of miracles during the operation indicates that miracles are closely tied to an acceptable "miraculous" vocabulary. While in biblical times, miracles in Judaism tended to violate nature, as noted, miracles in post-exile Judaism are in the timing. Here, too, even at their most extreme, battlefield miracles for Jewish soldiers are not extraordinary events. Additionally, the civilian reception of the events is closely related to tradition, with an aversion to the attempt to paint occurrences as miracles and a strong preference towards "rationalization" and interpreting them as "normal" events.

This begs the question, why were miracles reported during Cast Lead and what can they tell us about battlefield miracles in general. Following the hypotheses presented earlier, it seems that in the case of Cast Lead, soldiers felt God was on their side, were influenced by religious terminology, and might have felt a need to justify their actions to others. Furthermore, these were feelings contained within the battlefield and did not spill over into the civilian sphere. During "Cast Lead", the Chief Military Rabbi at the time, Avichai Rontzky, was very active in the field. Rabbi Rontzky, who also has an extensive combat background, showed a dynamic presence among troops before going into battle, blessing them, bringing a Torah scroll to where soldiers prepared for the operation and, in general, boosting morale using religious rhetoric. The use of religious terminology before battle may have placed troops in a proper mind-set to be open to the possibility of divine intervention on the battlefield.

Conversely, during the Operation Protective Edge (2014), the Chief Military Rabbi, Rafi Peretz, was not as active and religious terminology was not as prevalent in the field. This might explain the difference between the attitudes toward miracles in both cases..$^{30}$

An additional factor that might have contributed to the prevalence of miracles during the operation in this context, is the fact that in the past two decades, Israelis have become more traditional in their thinking and many are more open to folk religion than in the past (Fischer 2012; Shani 2015). The fact that the Israeli military is still conscription based and mirrors trends in Israeli society (Rosman and Israeli 2015), may contribute to the acceptance of folk-religious terminology in battle. In this sense, miracles are part of a folk-religious vocabulary. When soldiers are aware of the possibility of miracles, they are more open to experiencing them. Put together with the influence of Rabbi Rontzky, this may have contributed to the framing of events as miracles. Interestingly, miracles originated with and were accepted more by traditional soldiers, rather than mainstream religious soldiers. Further research is needed in order to explore these ideas further. The fact that the civilian sphere did not adopt the narrative that the events were miracles can be explained by the fact that civilians were not exposed to religious terminology in the same extreme situation. While the civilian population was subject to stress and violence, it was still not as an extreme situation as being in uniform in the battlefield, with all this entails. Put simply: despite having a traditional vocabulary to relate to, civilians felt safer than soldiers during the operation, were not as exposed to religious terminology during the time and were, therefore, not in a mindset receptive to viewing events as miraculous, as opposed to soldiers, who were.

\section{Conclusions}

29 For similar stories: (Tessler 2014).

30 During Operation Protective Edge, one of the brigade commanders (Ofer Winter) framed the battle in religious terms. However, contrary to the manner in which this was interpreted in the public, the fact that few miraculous events were reported may point to the conclusion that this was not a true introduction of religious terms into the battlefield. 
The current study includes specific findings concerning battlefield miracles, as well as more general lessons to be learned. In the more specific context, clearly, military miracles tend to appear when soldiers are given a religious context to relate to when going into battle. If a military uses religious terminology, or if soldiers are culturally inclined to accept religious terminology, there is a greater chance that military miracles will be reported. Additionally, when feeling a need to justify their actions, soldiers may be more inclined to witness miracles that "prove" they were acting positively.

On a more general level, this study stresses a number of points. All miracles require the proper audience and cultural context. The same is true of battlefield miracles. Rachel the Matriarch does not appear on the fields of Flanders and St. George does not warn Israeli soldiers in Gaza. Jewish soldiers tend to witness everyday miracles, not supernatural ones. Following the review of literature and the case study given here, a number of concepts can be stated. First, academic discourse must accept that, despite the philosophical argument, people believe in miracles. The question regarding the existence of miracles is irrelevant when looking at human experience on the battlefield. If soldiers are convinced they experienced a miracle, telling them they are wrong teaches us nothing.

Second, in the context of battle, a typology of miracles within four main categories can be created: incidents seen as against the normal course of nature versus everyday incidents perceived as miracles; incidents invoked by the divine versus those invoked by humans; occurrences perceived as doing good versus occurrences with other purposes (such as punishment); events understood as having a clear objective versus those that are not seen as having a clear message. Military miracles also fall into these categories, but their aim tends to be clearer. In the 21st century, as in the past, military witnesses to miracles are inclined to understand them as signs of heavenly favor and as a call to become more religious. In line with Jewish interpretation of miracles, Israeli military miracles do not intervene in nature. Their miraculous-ness is in their timing. This must still be examined in other religions and their effect on military miracles.

Third, contrary to the current view of the relationship between religion, the military and the state in Israel, battlefield occurrences in Israel are not framed as miracles by religious and secular leadership alike. Recognition of these occurrences as miracles are only from below, mainly from marginal sources. Soldiers themselves indicated that these incidents were interpreted as miracles, but the civilian religious establishment rejected this understanding and invested efforts in refuting claims of miraculous occurrences. This tension may point to a specific tendency in modern Judaism and to the relationship between religion and the public sphere in Israel. It is possible that while soldiers are more open to folk religion in this context, the civilian religious leadership is not. The gap between laypersons and leadership in terms of what acceptable religious practices are, may also play a part here. More comparative work is needed in order to explore this idea further.

Miracles are understood as response to a human need (Weddle 2010, pp. 26-27). As religion is a way of creating a sense of control and empowerment (Bromley 2007), so battlefield miracles are a way of coping with an extreme situation where soldiers find themselves with very little control over events. Based on the case of Cast Lead, it can be deduced that when the military in question uses religious terminology, feels local public support for the operation it is involved in, and also has a need to justify itself internationally, we can expect to hear of miracles.

This study also has limitations. Following miracles through their media coverage allows a specific vantage point and indicates the public acceptance (or rejection) of miracles. The current study does not hinge on personal testimony and, therefore, allows for a presentation of public attitudes. It examined more general tendencies following media studies indicating that there is a symbiotic relationship between public opinion and the media and that these mirror each other. It does not examine personal feelings of soldiers and use these to interpret the appearance of battlefield miracles. In addition, the current study did not examine battlefield miracles in a political or psychological context. There is still need for additional research approaches in order to broaden academic understanding of this phenomenon. For example, a psychological study of soldiers would also be illuminating and would present the subjective feelings of specific soldiers in specific situations. Likewise, examining the way religious leadership (civilian and military) relate to miracles is in order. 
The case study indicates that the majority of Israeli rabbis are apprehensive of this phenomenon and prefer to frame battlefield miracles as disconnected from the divine. ${ }^{31}$ Comparative work on other countries, religions, and battles will also broaden the understanding of battlefield miracles, their effect, and meanings.

Given the fact that military miracles continue to be reported across the globe, in different conflicts and religions, understanding what they mean to those who witness them is important. Such understanding helps us deduce what motivates troops in battle and what helps them cope with the results of their battlefield experiences. It also contributes to understanding how civilians understand military conflict and its aftermath.

Funding: This research received no external funding.

Conflicts of Interest: The author declares no conflict of interest.

\section{References}

(Al-Azzam n.d.) Al-Azzam, Abdullah. n.d. Signs from Ar-Rahman in the Jihad of Afghanistan. Edited by AlMehari, A.B. Birmingham: Maktabah. Available online: https://ia800502.us.archive.org/20/items/MiraclesOfJihadInAfghanistan-AbdullahAzzam/Signs_of_arRahman.pdf (accessed on 10 October 2018).

(Almond 1960) Almond, Gabriel. 1960. Introduction: A Functional Approach to Comparative Politics. In The Politics of Developing Areas. Edited by Almond Gabriel and Coleman James. Princeton: Princeton University Press, pp. 3-64.

(Ammerman 2014) Ammerman, Nancy T. 2014. Finding religion in everyday life. Sociology of Religion 75: 189207.

(Arutz 7 News 2009) Arutz 7 News. 2009. I Asked who Are You. She Said: Mother Rachel. Arutz 7 News, May 24. Available online: http://www.inn.co.il/News/News.aspx/189655 (accessed on 10 October 2018).

(Augustine 1876) Augustine, Saint. 1876. The Confessions. Edinburgh: Clark.

(Bardon 2016) Bardon, Aurélia. 2016. Religious Arguments and Public Justification. Religion, Secularism, and Constitutional Democracy. Edited by Jean L. Cohen and Cécile Laborde. Columbia: Columbia University Press, pp. 273-92.

(Basinger 2011) Basinger, David. 2011. What is a miracle? In The Cambridge Companion to Miracles. Edited by Graham H. Twelftree. Cambridge: Cambridge University Press, pp. 19-35.

(Baumgarten 1983) Baumgarten, Al. 1983. Miracles and Halakha in Rabbinic Judaism. Jewish Quarterly Review 73: 238-53.

(Bee 2009) Bee, Izzy. 2009. Apparition of Matriarch Rachel Protected IDF Soldiers inside Gaza, Top Rabbis Claim. Israelity Bites, January 27. Available online: http://israelitybites.blogspot.co.il/2009/01/apparition-ofmatriarch-rachel.html (accessed on 10 October 2018).

(Bilu and Ben-Ari 1995) Bilu, Yoram, and Eyal Ben-Ari. 1995. Modernity and charisma in contemporary Israel: The case of Baba Sali and Baba Baruch. Israel Affairs 1: 224-36.

(Birnbaum 1984) Birnbaum, Ruth. 1984. The Polemic on Miracles. Judaism 33: 439-47.

(Blau 2009a) Blau, Uri. 2009a. How G-d Fought in Gaza-Now the Film. Haaretz, May 5. Available online: http://www.haaretz.co.il/news/education/1.1259046 (accessed on 10 October 2018).

(Blau 2009b) Blau, Uri. 2009b. God is in the Shots. Haaretz-Weekend Supplement, May 8, p. 10.

(Bowie 2011) Bowie, Fiona. 2011. Miracles in traditional religions. In The Cambridge Companion to Miracles. Edited by Graham H. Twelftree. Cambridge: Cambridge University Press, pp. 167-83.

31 Miracles can be a double-edged sword, so to speak, for religious authorities. Post-Talmudic Judaism, as put forward, prefers to leave religion within the rational sphere. In this manner, the expectation for divine deliverance in extreme situations is not expected and failure of the divine to interfere on behalf of the faithful cannot be seen as a sign of disfavor or God forsaking his people. Acknowledging miracles would open the door for doubt in cases when God neglected to intervene and miraculously save the faithful. In this context, the present study strengthens the insight that modern Israeli rabbis are willing to accept the interpretation of broad natural occurrences as miracles (the Six Day War, for example, in its entirety, as an event) but not events such as those reported here. 
(Bromley 2007) Bromley, David G. 2007. On spiritual edgework: The logic of extreme ritual performances. Journal for the Scientific Study of Religion 46: 287-303.

(Burns 1981) Burns, Robert M. 1981. The Great Debate on Miracles. East Brunswick: Associated University Presses. (Caspi and Limor 1992) Caspi, Dan, and Yehiel Limor. 1992. The Mediators: Media in Israel 1948-1990. Tel Aviv: Am Oved. (In Hebrew)

(Caspi and Limor 1999) Caspi, Dan, and Yehiel Limor. 1999. The In/Outsiders: Mass Media in Israel. Cresskill: Hampton Press.

(Channel 2 News 2014) Channel 2 News. 2014. 47\% of Israelis Oppose Ground Operation in Gaza. Mako. Channel 2 News, July 10. Available online: http://www.mako.co.il/news-military/security/Articlee431896ac712741004.htm (accessed on 10 October 2018). (In Hebrew)

(Clarke 2002) Clarke, David. 2002. Rumours of Angels: A Legend of the First World War. Folklore 113: 151-72.

(Cohen 1997) Cohen, Stuart A. 1997. The Scroll or the Sword? Dilemmas of Religion and Military Service in Israel. Didcot: Taylor \& Francis.

(Cohen 2016) Cohen, Stuart A. 2016. Divine Service? Judaism and Israel's Armed Forces. Abingdon: Routledge.

(Cohen and Susser 2014) Cohen, Asher, and Baruch Susser. 2014. The Extreme Case Syndrome in Religion-Army Relationships. Civil-Military Relations in Israel: Essays in Honor of Stuart A. Cohen. Lanham: Lexington Books, p. 127.

(Cohen, 2008) Stuart A. 2008. "Israel and its Army." From Cohesion to Confusion. London and New York: Routledge. (Cohen-Almagor 1994) Cohen-Almagor, Raphael. 1994. The Boundaries of Tolerance and Liberty. Jerusalem: Nevo. (In Hebrew)

(Cohen-Almagor and Yanovitzky 1999) Cohen-Almagor, Raphael, and Novitzky Yanovitzky. 1999. The Conduct of the Media in the Eye of the Jewish Public in Israel: 'Is' versus 'Ought'. Megamot [Trends] 39: 400-19. (In Hebrew)

(D. Cohen 2009) Cohen, Dudu. 2009. I Am Rachel, Your Mother. Mako, February 16. Available online: http://www.mako.co.il/spirituality-popular_culture/Article-496ede451ae7f11004.htm (accessed on 10 October 2018). (In Hebrew)

(Dan 1990) Dan, Yosef. 1990. The Hasidic Story. Jerusalem: Keter. (In Hebrew)

(Daum 2009) Daum, Hanoch. 2009. The Story Stirring up the Sector. Yediot Ahronot, January 23, p. 18. (In Hebrew)

(Diamond 1973) Diamond, Malcolm L. 1973. Miracles. Religious Studies 9: 307-24.

(Fiordalis 2012) Fiordalis, David V. 2012. Miracles in Indian Buddhist narratives and doctrine. Journal of the International Association of Buddhist Studies 33: 381-408.

(Fischer 2012) Fischer, Shlomo. 2012. Yes, Israel is becoming more religious. Israel Studies Review 27: 10-15.

(Freeman and Wright 2001) Freeman, Robert C., and Dennis A. Wright, eds. 2001. Saints at War: Experiences of Latter-Day Saints in World War. American Fork: Covenant Communications Inc.

(Garland 2011) Garland, Robert. 2011. Miracles in the Greek and Roman World. In The Cambridge Companion to Miracles. Edited by Graham H. Twelftree. Cambridge: Cambridge University Press, pp. 75-94.

(Gazit 2009) Gazit, Gabi. 2009. Did Rachel the Matriarch Work Miracles for Soldiers during Cast Lead? Radio 103, May $6 . \quad$ Available online: http://103fm.maariv.co.il/programs/Media.aspx?ZrqvnVq=EKIKGL\&c41t4nzVQ=EE (accessed on 10 October 2018). (In Hebrew)

(Geiger and Dale 2009) Geiger, John, and Jennifer Dale. 2009. The Third Man Factor: The Secret to Survival in Extreme Environments. Melbourne: Text Publishing Company.

(Gilman 1989) Gilman, James E. 1989. Reconceiving Miracles. Religious Studies 25: 477-87.

(Goodwin 2015) Goodwin, Leslie. 2015. The Miracles that Saved Me in WWII. Tuolumne Veterans History Project: The Memoir Center. Available online: http://memoircenter.com/leslie-goodwin-the-miracles-that-saved-mein-wwii/ (accessed on 10 October 2018).

(Hassner 2014) Hassner, Ron E., ed. 2014. Religion in the Military Worldwide. Cambridge: Cambridge University Press.

(Hassner 2016) Hassner, Ron. 2016. Religion on the Battlefield. Ithaca: Cornell University Press.

(Hegghammer 2010) Hegghammer, Thomas. 2010. Jihad in Saudi Arabia: Violence and Pan-Islamism since 1979. Cambridge: Cambridge University Press, vol. 33.

(Heilman and Witztum 2000) Heilman, Samuel C., and Eliezer Witztum. 2000. All in faith: Religion as the idiom and means of coping with distress. Mental Health, Religion \& Culture 3: 115-24.

(Heschel 1955) Heschel, Abraham J. 1955. God in Search of Man. London: Macmillan. 
(Hume [1777] 1900) Hume, David. 1900. Of Miracles. In An Enquiry Concerning Human Understanding. Chicago: Open Court Publishing, p. 120. First published 1777.

(Issacs 1997) Issacs, Ronald H. 1997. Miracles: A Jewish Perspective. Northvale: Jason Aronson.

(Lamont 2013) Lamont, Peter. 2013. Extraordinary Beliefs: A Historical Approach to a Psychological Problem. Cambridge: Cambridge University Press.

(Landrum 1976) Landrum, George. 1976. What a Miracle Really Is. Religious Studies 12: 49-57.

(Larmer 2011) Larmer, Robert A. 2011. The Meanings of Miracle. In The Cambridge Companion to Miracles. Edited by Graham H. Twelftree. Cambridge: Cambridge University Press, pp. 36-53.

(Levy 2015) Levy, Yagil. 2015. The Divine Commander: The Theocratization of the Israeli Military. Tel Aviv: Am Oved and Sapir Academic College. (In Hebrew)

(Limor et al. 2014) Limor, Yichiel, Baruch Leshem, and Leah Mandelzis. 2014. Public Relations-Strategy and Tactics. Ra'anana: The Open University. (In Hebrew)

(Loebenstein 2003) Loebenstein, Judith. 2003. Miracles in Si'i Thought: A Case Study in the Miracles Attributed to Imam Gafar Al-Sadiq. Arabica 50: 199-244.

(Machen 1915) Machen, Arthur. 1915. The Bowmen: Introduction. Available online: http://gaslight.mtroyal.ab.ca/bowintro.htm (accessed on 10 October 2018).

(Mackler 2007) Mackler, Aaron L. 2007. Eye on religion: A Jewish view on miracles of healing. Southern Medical Journal-Birmingham Alabama 100: 1252-54.

(McClure 1994) McClure, Kevin. 1994. Visions of Bowmen and Angels. More Magonia. Available online: http://moremagonia.blogspot.co.uk/2011/09/mufob-new-series-1975-1979.html accessed on 10 October 2018).

(Miles et al. 1994) Miles, Matthew B., A. Michael Huberman, Michael A. Huberman, and Michael Huberman. 1994. Qualitative Data Analysis: An Expanded Sourcebook. Thousand Oaks: Sage.

(Miracles in the Jihad in Afghanistan 2015) Miracles in the Jihad in Afghanistan. 2015. (Film-No Author), July 2010. Available online: https://www.youtube.com/watch?v=6P2453ZuWMk (accessed on 10 October 2018).

(Moberly and Walter. 2011) Moberly, R., and L. Walter 2011. Miracles in the Hebrew Bible. In The Cambridge Companion to Miracles. Edited by Graham H. Twelftree. Cambridge: Cambridge University, pp. 57-74.

(Nahshoni 2009a) Nahshoni, Kobi. 2009a. Rabbi Eliyahu: I Sent Rachel the Matriarch to Save Soldiers. Ynet, January 20. Available online: http://www.ynet.co.il/articles/0,7340,L-3659188,00.html (accessed on 10 October 2018). (In Hebrew)

(Nahshoni 2009b) Nahshoni, Kobi. 2009b. Rabbi Yosef Describes Rachel's 'Manifestation' in Gaza. Ynet-English Edition. January 25. Available online: http://www.ynetnews.com/articles/0,7340,L-3661283,00.html (accessed on 10 October 2018).

(Ovadiya 2009) Ovadiya, Yuval. 2009. How God Fought in Gaza (Keytzad Elokim Nilham BeAza). Available online: https://www.youtube.com/watch?v=DhSz6YI1W8s (accessed on 10 October 2018).

(Ovadiya 2014) Ovadiya, Yuval. 2014. Protective Edge, Pillar of Clouds (Tzuk Eitan, Amud Anan). Available online: https://www.youtube.com/watch?v=YzYE7IqkKCs> (accessed on 10 October 2018). (In Hebrew)

(Pargament 2011) Pargament, Kenneth I. 2011. Spiritually Integrated Psychotherapy: Understanding and Addressing the Sacred. New York: Guilford Press.

(Pargament et al. 1990) Pargament, Kenneth I., David S. Ensing, Kathryn Falgout, Hannah Olsen, Barbara Reilly, Kimberly Van Haitsma, and Richard Warren. 1990. God help me:(I): Religious coping efforts as predictors of the outcomes to significant negative life events. American Journal of Community Psychology 18: 793-824.

(Pargament et al. 1992) Pargament, Kenneth I., Hannah Olsen, Barbara Reilly, Kathryn Falgout, David S. Ensing, and Kimberly Van Haitsma. 1992. God help me (II): The relationship of religious orientations to religious coping with negative life events. Journal for the Scientific Study of Religion 31: 504-13.

(Patton 1990) Patton, Michael Quinn. 1990. Qualitative Evaluation and Research Methods. Thousand Oaks: SAGE Publications, Inc.

(Pearl 1988) Pearl, Leon. 1988. Miracles and Theism. Religious Studies 24: 483-95.

(Roeh 1994) Roeh, Yoni. 1994. A Different Look at the Media: Seven Approaches to Examining Media and Journalism, Tel Aviv: Rekhes. (In Hebrew).

(Rosman and Israeli 2015) Rosman, Elisheva, and Zipi Israeli. 2015. From 'Rambo' to 'sitting ducks' and back again: The Israeli soldier in the media. Israel Affairs 21: 112-30.

(Rosman-Stollman 2014) Rosman-Stollman, Elisheva. 2014. For God and Country?: Religious Student-soldiers in the Israel Defense Forces. Austin: University of Texas Press. 
(Schulz 2013) Schulz, Heiko. 2013. The Concept of Miracle and the Concepts of Reality. Miracles Revisited: New Testament Miracle Stories and Their Concepts of Reality 2: 351.

(Seidman 2013) Seidman, Irving. 2013. Interviewing as Qualitative Research, 4th ed. New York: Columbia University.

(Sered 1991) Sered, Susan. 1991. Rachel, Mary and Fatima. Cultural Anthropology 6: 131-46.

(Sered 1995) Sered, Susan Starr. 1995. Rachel's Tomb: The Development of a Cult. Jewish Studies Quarterly 2: $103-$ 48.

(Shani 2015) Shani, Ayelet. 2015. Everyone Has a Little Garboz Inside. Haaretz, Weekend Supplement, May 22, pp. 16-18. (In Hebrew)

(Shattuck 1987) Shattuck, Gardiner H. 1987. A Shield and Hiding Place: The Religious Life of the Civil War Armies. Meacon: Mercer University Press.

(Sikhi Wiki 2012) Sikhi Wiki. 2012. A Miracle during World War II. Available online: http://www.sikhiwiki.org/index.php/A_Miracle_During_World_War_II (accessed on 10 October 2018).

(Stolz 2011) Stolz, Jörg. 2011. All Things Are Possible: Towards a sociological explanation of Pentecostal miracles and healings. Sociology of Religion 72: 456-82.

(Stout 2010) Stout, Mark. 2010. Jihadist Battlefield Miracles. On War and Words, February 26. Available online: https://onwarandwords.wordpress.com/2010/02/26/jihadist-battlefield-miracles/ (accessed on 10 October 2018).

(Taylor 2007) Taylor, James E. 2007. Hume on Miracles: Interpretation and Criticism. Philosophy Compass 2: 61124.

(Tessler 2014) Tessler, Yitzhak. 2014. On Miracles and Testers: The War for Jewish Consciousness on the Web. Ynet, August 8. Available online: http://www.ynet.co.il/articles/0,7340,L-4555671,00.html (accessed on 10 October 2018). (In Hebrew)

(TFP Student Action n.d.) TFP Student Action. n.d. Incredible Miracle: U.S. Marine Saved by Saint Michael. Available online: http://www.tfpstudentaction.org/resources/prayers-for-students/incredible-miracle-usmarine-saved-by-saint-michael.html (accessed on 10 October 2018).

(Thomas 2005) Thomas, Glenn. 2005. Miracles on the Front Lines. Charisma Magazine, March 31. Available online: http://www.creationists.org/angels-in-iraq-book.html (accessed on 10 October 2018).

(Thomas 2006) Thomas, David R. 2006. A general inductive approach for analyzing qualitative evaluation data. American Journal of Evaluation 27: 237-46.

(Weddle 2010) Weddle, David L. 2010. Miracles: Wonder and Meaning in World Religions. New York: NYU Press.

(Winer 2014) Winer, Stuart. 2014. Senior Infantry Officer Describes Divine Protection in Gaza. Times of Israel, July 31. Available online: http://www.timesofisrael.com/senior-infantry-officer-describes-divine-protection-ingaza/ (accessed on 10 October 2018).

(Witvliet et al. 2004) Witvliet, Charlotte V.O., Karl A. Phipps, Michelle E. Feldman, and Jean C. Beckham. 2004. Posttraumatic mental and physical health correlates of forgiveness and religious coping in military veterans. Journal of Traumatic Stress 17: 269-73.

(Yagna 2009) Yagna, Yanir. 2009. Rabbis Promised the Holy Men Would Protect Netivot and then a Rocket Fell Near the Grave of the Baba Sali. Haaretz, January 2, p. 8. (In Hebrew)

(Yahadoot 2012) Yahadoot. 2012. Personal Testimonies: Miracles during Cast Lead. Yahadoot, July. Available online: http://www.yahadoot.net/item.asp?id=574\&cid=15 (accessed on 10 October 2018). (In Hebrew)

(Zelyck 2016) Zelyck, Lorne R. 2016. Elisha Typology in Jesus' Miracle on the Jordan River (Papyrus Egerton 2, 2v. 6-14). New Testament Studies 62: 149-56.

(Zini 2009a) Zini, Yosef. 2009a. Dry Your Eyes: On the Appearance of Rachel the Matriarch. Behadrei Haredim Internet Forum, January 28. Available online: http://www.bhol.co.il/forums/topic.asp?topic_id=2567352\&forum_id=771 (accessed on 10 October 2018). (In Hebrew)

(Zini 2009b) Zini, Yosef. 2009b. Gentlemen, Stop Gossiping. Ynet, January 25. Available online: http://www.ynet.co.il/articles/0,7340,L-3661246,00.html (accessed on 10 October 2018).

(Zini 2009c) Zini, Yosef. 2009c. Rachel the Matriarch: Letters to the Editor. Yisrael Hayom, January 26, p. 23. (In Hebrew) 